\title{
Disturbance and Revegetation of Sonoran Desert Vegetation in an Arizona Powerline Corridor
}

\author{
M.B. HESSING, AND C.D. JOHNSON
}

\begin{abstract}
Rates and patterns of revegetation were studied during and after construction of the $500 \mathrm{kV}$ Navajo Project Southern Transmission Line at two sites in the A rizona Sonoran Desert from 1972 through 1977. Herbs were reduced temporarily during the construction phase of the study. Perennial herbs did not return in the 5-year post-construction period. Annual herbs invaded immediately after disturbance. In one case annual herb density and diversity was higher after disturbance due to removal of larger woody plants. The tree and shrub community exhibited dynamic changes in cover, diversity, and richness, presumably in response to the climate. However, colonization by new species was not observed during the 5 years of study. Colonization by previously existing species seemed to be limited to $A$ mbrosia deltoidea, probably due to its ability to reproduce vegetatively and to annual herbs. Annuals which were also on two control plots were probably a colonizing sere of plants.
\end{abstract}

Patterns of revegetation and plant succession in arid areas have been documented by only a few researchers. Wells (1961) described a specialized community, with more species than the climax, that established itself on the deserted streets of a Nevada ghost town. The specialized community persisted in marginal areas such as arroyo bottoms where the neighboring climax was prevented from becoming established, probably because of natural disturbances therc. Its presence on the strects was thought to be due to the removal of the more competitive climax shrubs. The results obtained by Vasek, et al. (1975) were similar, especially that washes served as refugia for pioneering species. However, they also emphasized that the early successional species composed a significant proportion of the undisturbed vegetation.

The ability of the original plants to regrow, either from seeds or rhizomes may also be a crucial factor in patterns of revegetation. Egler (1954) and Connell and Slatyer (1977) have discussed this concept and Niering and Goodwin (1974) have shown its importance under a powerline in Connecticut.

We studied revegetation and colonization of plants before, during, and after construction of the $500 \mathrm{kV}$ Navajo Project Southern Transmission Line (NPSTL), which connects the Navajo Power Plant in Page, Arizona, with Phoenix, Arizona. Construction was initiated in 1972 when a survey strip varying from $7 \mathrm{~m}$ to over $20 \mathrm{~m}$ wide was cleared by bulldozers. The middle of the survey strip received additional use as an access road while pylons and powerlines were erected in 1973.

We chose two areas along the powerline which had received different degrees of disturbance. At Site 1, vegetation and the top

\footnotetext{
Authors are with the Department of Biological Sciences, Northern Arizona University, Flagstaff 86011 .

Authors thank Arizona Public Service Company. Tucson Gas and Electric Company, and Salt River Project for funds to conduct this research.

Manuscript received September 18, 1980.
}

several inches of soil were removed on a hillside. At Site 2 large trees, cacti, and shrubs were removed, but removal of small shrubs such as bur-sage (Ambrosia deltoidea (Torr.)) and prickly pear cactus (Opuntia probably phaeacantha Engelm.) was not complete.

We utilized the disturbance caused by the construction of the powerline to assess the rate and pattern of naturally occurring revegetation and to find evidence of a sere of colonizing plants in the first 5 years following disturbance.

\section{Description of the Study Areas}

Site 1 was located in a Sonoran Desert scrub-Arizona Upland Subdivision (Lowe and Brown 1973) along Table Mesa Road about $45 \mathrm{~km}$ north of Phoenix, Maricopa County, Arizona, at an elevation of $670 \mathrm{~m}$. The National Weather Service recording station at Cave Creek ( $646 \mathrm{~m}$ in elevation and approximately $20 \mathrm{~km}$ to the southeast) averages $28.2 \mathrm{~cm}$ of rainfall annually. The terrain is hilly and is dominated by a diverse shrub community. The dominant species is bur-sage, although other larger shrubs and small trees are frequently interspersed. The larger individuals, especially palo-verde (Cercidium microphyllum (Torr.) Rose \& Johnston), create a microclimate favoring the establishment of grasses, other shrubs, and cacti (Hastings and Turner 1965; Brum 1973).

Site 2 was located on a flat alluvial plain, at an elevation of $457 \mathrm{~m}$ also in the Sonoran Desert scrub-Arizona Upland Subdivision, 2 $\mathrm{km}$ south of the Lake Pleasant, Maricopa County, Arizona, National Weather Service station, where $25.9 \mathrm{~cm}$ of rain are reported annually. Vegetation is more sparse than at Site 1. Bursage is the most dominant shrub, although small aggregations of other shrubs abound, especially string-of-beads cholla (probably Opuntia fulgida Engelm.), teddy-bear cholla (Opuntia bigelovii Engelm.), and creosote-bush (Larrea tridentata (DC) Coville). Annuals did not grow at these sites during the early summer because of the lack of rainfall.

\section{Methods and Materials}

Soil-Soil samples were collected from cleared and control plots in 1972 (the year of survey strip construction) and in 1974, one year after pylon construction. The soils were analyzed for texture, organic matter, concentration of soil salts, electric conductance, and $\mathrm{pH}$ by the Soils, Water, and Engineering Department of the University of Arizona, Tucson.

Climate - At Site 2, two United States Weather Bureau Standard rain gauges were placed on each plot and measured and emptied periodically thereafter until spring 1977 . Temperature and relative humidity were measured at both sites with Honeywell constantly recording hygrothermographs, two per plot, each housed separately in white weather boxes located at either end of the plot. Rainfall, temperature, and relative humidity created a 
noncontinuous data source suited primarily to comparing data from under the line to data from control areas.

Vegetation-At both sites, two subplots measuring $15.2 \mathrm{~m}$ by $45.7 \mathrm{~m}$ were staked and flagged so they formed a large rectangle $15.2 \mathrm{~m}$ by $91.4 \mathrm{~m}$ situated lengthwise underneath the powerline. Control subplots of the same size were staked out in similar vegetation directly parallel and $45.7 \mathrm{~m}$ to the east of all disturbed plots. At Site 2 an additional plot was added to increase the sample size for tree and shrub data. After construction, the access road at Site 2 was not effectively closed and received continued use. Because of this use, in 1973 two of the three disturbed tree and shrub subplots and one of the two disturbed herb subplots were relocated immediately adjacent to the access road, yet still within the survey strip. At Site 1 small portions of undisturbed habitat and survey strip edge were included in the disturbed plot because the width of the survey strip varied.

At Site 1, in spring 1973, the corridor was cleared during construction as much as $35 \mathrm{~m}$ west of the original survey stakes and the original study plots. We moved the disturbed plot so that it encompassed the access road and corridor. Because of this, our 1972 data are not directly comparable to the other data. For the remainder of the study, the disturbed plot was on a small hillside with slight vegetation differences from the control plot. Censuses were begun in summer 1972 and ended in spring 1977. Herbs were censused in January or in the spring when they were judged to be at their peak growth. Trees and shrubs were censused in the summer and in the spring of 1976 and 1977 to check for seasonal variation.

Census and analysis techniques have been described (Hessing 1978, Hessing et al. 198 la). We reiterate a few of the important points. In each of two subplots, eleven 7.6-m fixed-location line transects were used to measure herb cover. All large, woody plants in the total plot area were measured individually. Occasionally, small woody plants were measured with herbs to increase ease and accuracy of censuses.

We used relative cover to obtain a similarity index, $\mathrm{C}_{\lambda}$ (Morisita 1959), and a diversity index, $\mathrm{E}(\mathrm{H})$ (Poole 1974). Standard reference texts were used for plant names and identification (Kearney and Peebles 1960, Benson 1969).

Cover from parallel plots was compared using a series of oneway analyses of variance on data from each census period and two-way analyses of variance on different combinations of yearly data. $E\left(H^{\prime}\right)$, a corrected form of the Shannon-Wiener index of diversity, was subjected to $t$-tests as described in Poole (1974). We include data on species richness as an alternative to this index.

\section{Results and Discussion}

Weather-At Site 1 no consistent differences in temperature or relative humidity were recorded between the disturbed and control plots.

At Site 2 we measured similar amounts of rain on the disturbed plot and on the control plot. Hygrothermograph data showed a seasonal component. Disturbed plot temperature (mean, mean low, and mean high) was lower than on the control plot in the spring, similar in the summer, and higher in the fall and winter. Disturbed plot relative humidity (mean, mean low, and mean high) was similar to the control plot in the spring, and tended to be more extreme in the summer and fall (high was higher, low was lower), and lower in the winter, although these differences were not always statistically significant. Patten (1978) reports that air temperature and soil moisture in the Sonoran Desert were moderated by shrub or tree canopies, which seems a reasonable explanation for the differences measured.

Results were so variable both within and between other areas underneath the powerline (Hessing 1978) that we concluded that differences were not due to the constant physical presence of the powerline or the electrostatic forces it generated.

Soil--These loam to sandy clay loam and sandy loam soils exhibited considerable variation in constituents. Some trends or differences between disturbed and undisturbed soils are evident but none are statistically defendable. The occasional variations in soil salts that we found can be attributed to sampling variation and natural conditions in the environment. This was surprising because at Site 1 top soil had been removed when the access road was cut into the hillside.

Site 1, Trees and Shrubs-Table 1 indicates considerable change in the number of species. The disturbed plot harbored 14 species of woody plants in 1974 and 18 in 1976 . The control plot harbored 13 species in 1975 and 17 in 1976 . Species number increased greatly in the spring censuses. In both 1976 and 1977 , the disturbed plot had 24 species and the control plot had 21 species.

Control plot cover has increased steadily since 1973 whereas disturbed plot cover has not increased and the one-way analysis of variance (Table 1) shows significant differences between plots only in the last three censuses. In 1975 there was $16.3 \%$ more cover on the control plot, yet statistical significance could not be demonstrated due to high sample variability. Control plot samples in 1975 ranged from $14.3 \%$ cover to $159.3 \%$ cover, and disturbed plot samples ranged from $3.8 \%$ cover to $61.6 \%$ cover. In a two-way analysis of variance cover on the control plot did exceed the cover of the disturbed plot.

Cover values of $159.3 \%$ occurred where large trees and shrubs so enhanced microclimatic conditions that smaller shrubs and herbs proliferated in their shade. These conditions also seem to be favorable for large cacti such as Cereus and Echinocactus. There appears to be competition for shade and protection.

The largest differences between the amount of cover on the two plots was expected immediately following disturbance with subsequent, gradual lessening of differences. Just the opposite pattern occurred (Table 1). Differences were smallest immediately after disturbance and have steadily increased since that time. The reason for this is not entirely clear, although two factors are known to influence this condition. First, the edge effect (Johnson et al. 1975) would have been greatest immediately following disturbance when the access road was still hard-packed and would have decreased steadily. Second, the control plot, having more cover to begin with, is greatly enhanced by favorable climatic regimes. We hypothesize that in 1973 and 1974 cover should have decreased on both plots, but the decrease should be masked on the disturbed plot where the edge effect would increase cover. In later years, the control plot should have responded to favorable climatic conditions to a far greater extent than the disturbed plot which would no longer be augmented by the edge effect.

Community similarity (Table 1) was high and fluctuated little. The high values of $C_{\lambda}$ were a result of one species, bur-sage, being found in high proportions on both plots.

As rainfall increased, more rare plants became active and were recorded in the census. Increased rainfall augmented growth of bur-sage and other dominants. This is why the number of species (Table 1) frequently increased as cover increased while the diversity index $\mathrm{E}\left(\mathrm{H}^{\prime}\right)$ (Table 1), which incorporates the evenness of species distribution, frequently declined as cover increased.

Differences in $\mathrm{E}\left(\mathrm{H}^{\prime}\right)$ were significant in all years except 1973. The reason that the disturbed plot was more diverse was partially due to its position on a hillside. However, in two other semiarid communities (Hessing et al. 1981a,b) we found that disturbance raised diversity by interfering with the dominant species.

Beginning in 1973, any species which had not been recorded in a previous census on that plot was classified as an invader species. The control plot was the more likely place to observe invader species. It recruited 2.25 new species per year whereas the disturbed plot added 1.50 new species per year. Relatively little invasion or reestablishment was observed on the survey strip. The high values of $C_{\lambda}$ (Table 1) indicate that, if invasion has taken place, it is by species already common on the control plot and road edges. Heightened diversity on the disturbed plot is due to the location of the plot on a hillside and to a lack of dominance by bur-sage. The fluctuations in cover and diversity are due to changes in the dominant vegetation which was already established; they do not represent succession.

Vasek et al. (1975) stressed the extreme perenniality of Mojave 
Table 1. Summary data for the plant community at Site $1 . D=$ disturbed; $C=$ control. Standard error in parentheses.

\begin{tabular}{|c|c|c|c|c|c|c|c|}
\hline Attribute and treatment & 1972 & 1973 & 1974 & 1975 & 1976A & 1976B & 1977A \\
\hline \multicolumn{8}{|l|}{ Percent cover } \\
\hline \multicolumn{8}{|l|}{ Trees and Shrubs } \\
\hline \multirow[t]{2}{*}{ D } & 33.2 & 23.0 & 31.1 & 23.9 & 27.7 & 28.1 & 29.4 \\
\hline & $(2.9)$ & $(4.5)$ & (3.2) & $(4.2)$ & (3.3) & (4.4) & (5.4) \\
\hline \multirow[t]{2}{*}{$\mathrm{C}$} & 29.2 & 26.9 & 33.9 & 38.9 & 51.4 & 47.7 & 47.3 \\
\hline & $(2.9)$ & (3.5) & $(4.3)$ & (11.1) & $(4.6)$ & (7.6) & (4.9) \\
\hline \multicolumn{8}{|l|}{ Herbs } \\
\hline \multirow[t]{2}{*}{ D } & 3.1 & 3.9 & 4.3 & 1.9 & 3.5 & - & 3.6 \\
\hline & $(0.7)$ & $(0.8)$ & $(1.0)$ & $(0.4)$ & $(0.7)$ & - & $(0.1)$ \\
\hline \multirow[t]{2}{*}{$\mathbf{C}$} & 7.9 & 5.3 & 5.6 & 4.3 & 5.1 & - & 2.3 \\
\hline & $(1.6)$ & $(1.3)$ & $(1.4)$ & $(1.3)$ & (1.6) & - & $(1.1)$ \\
\hline \multicolumn{8}{|l|}{ Number of Species } \\
\hline \multicolumn{8}{|l|}{ Trees and Shrubs } \\
\hline D & 21 & 16 & 14 & 15 & 24 & 18 & 24 \\
\hline & 16 & 14 & 14 & 15 & 21 & 18 & 21 \\
\hline \multicolumn{8}{|l|}{ Herbs } \\
\hline D & 18 & 15 & 15 & 6 & 20 & - & 11 \\
\hline $\mathrm{C}$ & 16 & 13 & 13 & 11 & 15 & - & 13 \\
\hline \multicolumn{8}{|l|}{$\underline{\mathrm{C}_{\lambda}}$} \\
\hline Trees and Shrubs & 0.98 & 0.96 & 0.96 & 0.9 & 0.96 & 0.95 & 0.93 \\
\hline Herbs & 0.87 & 0.35 & 0.4 & 0.54 & 0.75 & - & 0.05 \\
\hline \multicolumn{8}{|l|}{ Percent of Herbs } \\
\hline \multicolumn{8}{|l|}{$\begin{array}{l}\text { that are Perennial } \\
\text { Species }\end{array}$} \\
\hline D & 8.7 & 11.8 & 12.7 & 2.9 & 5.3 & - & 2.3 \\
\hline C & 19.5 & 21.3 & 59.5 & 36.8 & 39.6 & - & 82.9 \\
\hline \multicolumn{8}{|l|}{ ANOVA (cover) } \\
\hline Trees and Shrubs & $\begin{array}{l}.29 \\
\text { (NS)! }\end{array}$ & $\begin{array}{l}.61 \\
\text { (NS) }\end{array}$ & $\begin{array}{l}.32 \\
\text { (NS) }\end{array}$ & $\begin{array}{l}.18 \\
\text { (NS) }\end{array}$ & .0004 & .0359 & .023 \\
\hline Herbs & .009 & $\begin{array}{l}38 \\
\text { (NS) }\end{array}$ & $\begin{array}{l}.48 \\
\text { (NS) }\end{array}$ & $\begin{array}{l}.08 \\
\text { (NS) }\end{array}$ & $\begin{array}{l}.36 \\
\text { (NS) }\end{array}$ & - & $\begin{array}{l}.35 \\
\text { (NS) }\end{array}$ \\
\hline \multicolumn{8}{|l|}{ Diversity $\left(\mathbf{H}^{\prime}\right)$} \\
\hline \multicolumn{8}{|l|}{ Trees and Shrubs } \\
\hline D & 1.59 & 1.37 & 1.4 & 1.7 & 1.5 & 1.6 & 1.5 \\
\hline C & 1.1 & 1.3 & 1.2 & 1.7 & 1.2 & 1.1 & 0.8 \\
\hline t-value & $11.6 * 2$ & 0.9 & $2.9^{*}$ & $12.0^{*}$ & $5.9^{*}$ & $11.1 *$ & $15.1^{*}$ \\
\hline \multicolumn{8}{|l|}{ Herbs } \\
\hline D & 2.2 & 2.0 & 2.0 & 1.2 & 1.6 & - & 1.6 \\
\hline C & 2.0 & 1.6 & 1.6 & 1.8 & 1.5 & - & 1.3 \\
\hline t-value & 2.3 & $3.7^{*}$ & $3.3^{*}$ & $-6.6^{*}$ & 1.9 & - & 2.3 \\
\hline
\end{tabular}

INS $=$ not significant

2* significant at $\mathrm{P}=0.005$ level.

Desert shrubs. They suggest that perenniality may be inversely correlated with replacement rate. Their evidence supports the view that colonization involves a sere of short-lived shrubs. Wells (1961) and Vasek et al., (1975) recognized a guild of colonizing shrubs usually occurring in slightly disturbed areas such as dry washes. The only shrub observed to have become established on the maximally disturbed access road was bur-sage, even though a dry wash was close. This shrub is rhizomatous (Harper 1977) and some of the new shrubs may be the product of asexual propagation. Reestablishment from seeds is more the exception than the rule for desert shrubs; germination occurs after the first spring rains (Shreve 1917) and it is unlikely that large-scale success ever results (Barbour 1968).

Site 1, Herbs-The herb community of the two plots was not similar and was subject to extreme variation in species similarity from year to year. $C_{\lambda}$ (Table 1 ) declined from $C_{\lambda}=.748$ in spring 1976 , to $C_{\lambda}=.052$ in spring 1977.

Generally, the disturbed plot diversity was greater than that of the control plot. The exception was 1975 when both $\mathrm{E}\left(\mathrm{H}^{\prime}\right)$ and the number of species was greater on the control plot (Table 1).

A category which included all perennial herbs is presented in Table 1. It is clear that the control plot herb community was composed of a larger proportion of perennials than the disturbed plot. Neither plot was consistently more amenable to invader species.

Disturbance has not increased the amount of herb cover (Table 1), but it has increased the diversity slightly and caused differences from the control plot flora. Although perennial herbs are not common at this arid site, the control plot herb community harbors more perennials than the disturbed plot.

Herb cover is gradually increasing on the disturbed plot (Table 1). Because the original seed bank was probably disturbed during construction, it is expected that herb growth will increase as seeds continue to colonize the roadway.

Site 2, Trees and Shrubs-In 1972 and 1973, before and during construction, respectively, there was little difference in cover between plots (Table 2). After 1973 there was more cover on the control plot, although the difference was not significant in the spring of 1976. A two-way analysis of variance showed that yearly conditions did not interact with the proportion of cover found on either plot and that in any grouping of years the control plot had greater cover than the disturbed plot.

The two plots remained highly similar in species composition throughout the study (Table 2 ). If construction caused any immediate change, it was to increase similarity with a slight trend toward 
Table 2. Summary data for the plant community at Site $2 . D=$ disturbed; $C=$ control. Standard error in parentheses.

\begin{tabular}{|c|c|c|c|c|c|c|c|}
\hline Attribute and treatment & 1972 & 1973 & 1974 & 1975 & $1976 \mathrm{~A}$ & 1976B & $1977 \mathrm{~A}$ \\
\hline \multicolumn{8}{|l|}{ Percent cover } \\
\hline \multicolumn{8}{|l|}{ Trees and Shrubs } \\
\hline D & $\begin{array}{c}9.1 \\
(1.2)\end{array}$ & $\begin{array}{l}10.5 \\
(1.7)\end{array}$ & $\begin{array}{l}10.5 \\
(2.6)\end{array}$ & $\begin{array}{r}5.3 \\
(1.3)\end{array}$ & $\begin{array}{r}5.8 \\
(1.6)\end{array}$ & $\begin{array}{c}4.8 \\
(1.4)\end{array}$ & $\begin{array}{r}5.0 \\
(1.4)\end{array}$ \\
\hline C & $\begin{array}{l}10.0 \\
(1.5)\end{array}$ & 11.8 & 21.4 & 15.8 & 9.3 & 10.3 & 10.3 \\
\hline \multicolumn{8}{|l|}{ Herbs } \\
\hline D & - & 18.5 & 15.3 & 6.1 & 36.2 & 5.7 & 30.3 \\
\hline & & (3.4) & (2.3) & (1.3) & (2.3) & $(0.7)$ & (2.8) \\
\hline $\mathrm{C}$ & - & 35.0 & 4.2 & 7.9 & 31.2 & 5.3 & 23.8 \\
\hline \multirow{2}{*}{\multicolumn{8}{|c|}{ Number of Species }} \\
\hline & & & & & & & \\
\hline \multicolumn{8}{|l|}{ Trees and Shrubs } \\
\hline D & $\begin{array}{l}10 \\
13\end{array}$ & $\begin{array}{r}4 \\
10\end{array}$ & 11 & $\begin{array}{r}4 \\
12\end{array}$ & 14 & 13 & $\begin{array}{r}4 \\
13\end{array}$ \\
\hline \multicolumn{8}{|l|}{$\underset{\text { Herbs }}{C}$} \\
\hline D & - & 15 & 3 & 3 & 15 & 7 & 11 \\
\hline C & - & 15 & 2 & 3 & 13 & 7 & 13 \\
\hline \multicolumn{8}{|l|}{$C_{\lambda}$} \\
\hline Trees and Shrubs & 0.9 & 0.86 & 0.97 & 0.93 & 0.9 & 0.9 & 0.8 \\
\hline Herbs & - & 0.4 & 0.99 & 0.9 & 0.99 & 0.98 & 0.96 \\
\hline \multicolumn{8}{|l|}{ ANOV A (cover) } \\
\hline Trees and Shrubs & - & .0001 & .0000 & $\begin{array}{l}.295 \\
\text { (NS) }\end{array}$ & $\begin{array}{l}.085 \\
\text { (NS) }\end{array}$ & $\begin{array}{l}.598 \\
\text { (NS) }\end{array}$ & .04 \\
\hline Herbs & $\begin{array}{l}.33 \\
\text { (NS) }\end{array}$ & $\begin{array}{l}.58 \\
\text { (NS)' }\end{array}$ & .01 & .001 & $\begin{array}{l}.13 \\
\text { (NS) }\end{array}$ & .025 & .034 \\
\hline \multicolumn{8}{|l|}{ Diversity $\left(\mathrm{H}^{\prime}\right)$} \\
\hline \multicolumn{8}{|l|}{ Trees and Shrubs } \\
\hline D & 1.08 & 0.96 & 1.08 & 1.01 & 0.9 & 1.0 & 0.9 \\
\hline $\mathrm{C}$ & 1.6 & 1.6 & 1.6 & 1.6 & 1.6 & 1.7 & 1.7 \\
\hline $\mathrm{t}$-value & $-9.0^{* 2}$ & $-16.3^{*}$ & $-10.7^{*}$ & $-13.2^{*}$ & $-11.97^{*}$ & $-12.9 *$ & $-14.8 *$ \\
\hline \multicolumn{8}{|l|}{ Herbs } \\
\hline D & - & 1.97 & 0.4 & 0.8 & 0.95 & 0.69 & 0.88 \\
\hline C & - & 1.9 & 0.26 & 0.9 & 0.8 & 0.7 & 1.05 \\
\hline t-value & - & 2.04 & 2.01 & $-4.2^{*}$ & $4.7^{*}$ & -0.3 & $-6.9^{*}$ \\
\hline
\end{tabular}

INS = not significant

2* significant at $\mathbf{P}=0.005$ level.

decreasing similarity in later years.

The diversity index $\mathrm{E}\left(\mathrm{H}^{\prime}\right)$ (Table 2) shows both plots retaining the same diversity throughout the seven censuses. Before disturbance, the disturbed plot harbored ten species, three less than the control plot at that time. Since disturbance, only four species have been recorded, whereas the control plot averaged 13 species in the last four censuses.

The data provide no evidence for colonization or successional change of woody plants. The amount of cover and number of species were reduced by construction and they have not recovered. Bur-sage dominates both plots so that species similarity remained high before and after disturbance.

Yeaton et al. (1977) give good evidence that, despite generous spacing between woody plants in the upland association, competition exists intra- and inter-specifically and restricts plant size. Although they suggest simple root competition as the cause for reduced size, both creosote-bush and bur-sage hae been shown to give off allelochemic substances (Adams et al. 1970, Muller and Muller 1956), although the use of these in competitive interaction has not been verified. The data were plotted to see if there was a porportional increase in bur-sage as it responded to the reduction in competitors caused by the disturbance. No such response was seen although it would have explained the gradually decreasing trend in similarity indices. Neither did buckhorn cholla (probably Opuntia acanthocarpa Engelm \& Bigel.) show a pattern of response to disturbance. Yeaton et al. (1977) feel there is a little competition between these species (although they studied a conge- neric, Opuntia fulgida). The best explanation for the decline in similarity is a gradual loss of the rare species on the disturbed plot. During disturbance (but after the corridor had been cleared) there were four prickly pear cacti which have subsequently died. $C_{\lambda}$ is lower still in spring censuses when it is possible to differentiate two species of cholla (probably $O$. fulgida and $O$. acanthocarpa) on the disturbed plot. $O$. fulgida was not found on the control plot.

Site 2, Herbs-The access road was in use during our first census in spring 1973, and these data indicate the effect of disturbance. At that time, the control plot had significantly more herb cover than the disturbed plot (Table 2). One year later, in 1974, herb cover was significantly greater on the disturbed plot (Table 2). It was significantly greater again in 1977 , although confidence in making this decision is low $(p=.04)$.

Herbs germinate in November, grow throughout the winter and their peak growth is in the spring. In spring 1976 and 1977 , special attempts were made to census herb growth at the period of peak growth. At each census, vegetation was just starting to die due to lack of moisture, but shortly after the first two censuses additional rain fell, stimulating growth. When spring 1976 and 1977 censuses were pooled in the two-way analysis of variance, the disturbed plot had significantly more cover. Even the continued vehicular use of one subplot of the disturbed plot had not lessened its herb cover.

A significant interaction effect in the two-way analysis of variance supports the impression given by Table 2 that the disturbed plot exceeds the control plot when herb growth is maximal, such as the spring of 1976 and 1977. 
Similarity was greatly lowered in 1973 during construction when $C_{\lambda}$ dropped to .426. Species composition did not differ, but the absolute cover of existing species did. Since the $C_{\lambda}$ has remained extremely high (Table 2) indicating that similar species exist on the two plots.

Little difference in diversity exists between plots (Table 2). Although significant differences in $\mathrm{E}\left(\mathrm{H}^{\prime}\right)$ do exist $(1975,1976$, 1977), the plot with the highest diversity changes from census to census. Cover increases as a function of increasing the number of species (Table 2).

Patten (1978) has shown that ephemerals in the Sonoran Desert generally attained greatest productivity under light canopy cover (Cercidium), less productivity in tree and shrub interspaces, and the least productivity under dense canopy (Ambrosia). Hence, greater herb cover on areas cleared of Ambrosia is to be expected.

We conclude that removal of woody plants on the disturbed plot has cont ributed to significantly greater herb growth. Construction artificats such as depressions in the access road which collect water and seeds (Reichman and Oberstein 1977) also contribute to herb growth. In this study, vehicular use of the access road, most of which occurred after spring growth, did not greatly inhibit herb growth.

\section{Conclusions}

There was no evidence of succession or more than a trace of revegetation by woody plants at Site 1 . Yearly and seasonal conditions created a complex quantitative response of shrubs. Herb cover was reduced on the disturbed area, but only temporarily. Apparently, the removal of the shrubs and herbs allowed the establishment of annual herbs which were not always similar to herbs on the control plot. The control plot had several perennial herb species; the disturbed plot had none.

Woody plants at Site 2 did not reestablish themselves. Death of cacti and other shrubs often did not occur until several years after disturbance and caused a gradual decline in similarity. Disturbance at Site 2 increased the numbers of herbs there. Annual herbs (the only ones present) invaded immediately after disturbance and created a community highly similar to the control community.

At both sites, the disturbed plot herb community probably represented a seral stage.

What little shrub reestablishment we observed seemed to be the result of asexual reproduction. Consequently, we anticipate a different pattern of revegetation in areas where the original vegetation was destroyed (Site 1) than in areas where at least part of it was left intact (e.g., Site 2).

\section{Literature Cited}

Adams, S.B., B.R. Strain, and M.S. Adams. 1970. Water repellent soils, fire, and annual plant cover in a desert scrub community of southeastern California. Ecology 51:696-700.
Barbour, M.G. 1968. Germination requirements of the desert shrub Larrea divaricata. Ecology 49:915-923.

Benson, L. 1969. The cacti of Arizona. Univ. Arizona Press, Tucson, Ariz. $218 \mathrm{p}$.

Brum, G.D. 1973. Ecology of the Saguaro(Carnegiea gigantea): phylogeny and establishment in marginal populations. Madroño 22:195-203.

Connell, J.H., and R.O. Slatyer. 1977. Mechanisms of succession in natural communities and their role in community stability and organization. Amer. Natur. 111:1119-1144.

Egler, F.E. 1954. Vegetation science concepts I. initial floristic composition, a factor in old-field vegetation development. Vegetatio 4:412-417.

Harper, J.L. 1977. Population biology of plants. Academic Press, New York. 892 p.

Hasting, J.R., and R.M. Tumer. 1965. The changing mile. Univ. Arizona Press, Tucson, Ariz. 317 p.

Hessing, M.B. 1978. Secondary succession in powerline corridors in Northern Arizona desert and semiarid plant communities. M.S. Thesis, Northern Arizona Univ., Flagstaff, Ariz.

Hessing, M.B., C.D. Johnson, and R.P. Balda. 1981a. Early secondary succession of a pinyon-juniper woodland in a Northern Arizona powerline corridor. Southwestern Natur. (in press).

Hessing, M.B., C.D. Johnson, and R.P. Balda. 1981b. Secondary succession of desert grassland in North-central Arizona powerline corridors. J. Environ. Manage. 13(1):55-69.

Johnson, H.B., F.C. Vasek, and T. Yonkers. 1975. Productivity, diversity and stability relationships in Mojave Desert roadside vegetation. Bull. Torrey Bot. Club 102:106-115.

Keamey, T.H., and R.H. Peebles. 1960. Arizona flora. Univ. of California Press, Berkeley, Calif. 1085 p.

Lowe, C.H., and D.E. Brown. 1973. The natural vegetation of Arizona. Arizona Game and Fish Department. Sims Printing Co., Inc., Phoenix, Ariz.

Morisita, M. 1959. Measurement of interspecific association and similarity between communities. Memoirs of the Faculty of Science, Kyushu Univ., Series E (Biology) 2:215-235.

Muller, W.H., and C.H. Muller. 1956. Association patterns involving desert plants that contain toxic products. Amer. J. Bot. 43:354-361.

Niering, W.A., and R.H. Goodwin. 1974. Creation of relatively stable shrublands with herbicides: arresting "succession" on rights-of-way and pastureland. Ecology 55:784-795.

Patten, B.T. 1978. Productivity and production efficiency of an upper Sonoran desert ephemeral community. Amer. J. Bot. 65:891-895.

Poole, R.W. 1974. An introduction to quantitative ecology. McGraw-Hill Inc., New York, N.Y. 532 p.

Reichman, O.J., and D. Oberstein. 1977. Selection of seed distribution types by Dipodomys merriami and Perognathus amplus. Ecology 58:636-643.

Shreve, F. 1917. The establishment of desert perennials. J. Ecol. 5:210-216.

Vasek, F.C., H.B. Johnson, and D.H. Eslinger. 1975. Effects of pipeline construction on creosote scrub vegetation of the Mojave Desert. Madroño $23: 1-12$.

Wells, P.V. 1961. Succession in desert vegetation on streets of a Nevada ghost town. Science 134:670-671.

Yeaton, R.I., J. Travis, and E. Gilinsky. 1977. Competition and spacing in plant communities: the Arizona upland association. J. Ecol. 65:587-595. 